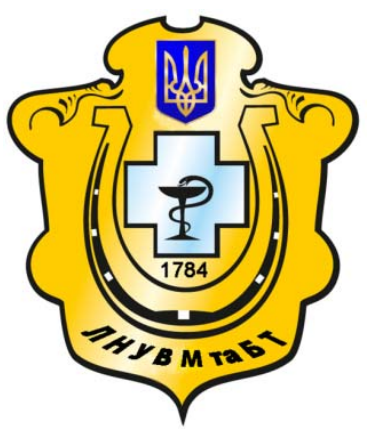

Науковий вісник Львівського національного університету ветеринарної медицини та біотехнологій імені С.3. Гжицького

Scientific Messenger of Lviv National University of Veterinary Medicine and Biotechnologies named after S.Z. Gzhytskyj

doi:10.15421/nvlvet7018

ISSN 2413-5550 print

ISSN 2518-1327 online

$\underline{\text { http://nvlvet.com.ua/ }}$

УДК 636.4:612.8

\title{
Взаємозв'язки інтенсивності пероксидного окиснення ліпідів із основними корковими процесами у поросят за стресу відлучення
}

\author{
О.В. Данчук, В.I. Карповський \\ olexdan@ukr.net \\ Національний університет біоресурсів і природокористування Украӥни, \\ вул. Героїв Оборони, 15, м. Київ, 03041, Украӥна
}

Технологічний стрес (відлучення) супроводжується зростанням вмісту ТБК-активних продуктів в еритроцитах та основ Шиффа у плазмі крові порося (в 1,8 - 2,6 рази; $p \leq 0,001)$, що є є загально біологічною особливістю і не залежить від типологічних особливостей вищої нервової діяльності. Встановлені функціональні зв'язки та вплив коркових процесів на вміст ТБК-активних продуктів в еритроцитах та основ Шиффа у плазмі крові поросят. Обернені функціональні зв'язки основних властивостей коркових процесів із вмістом ТБК-активних продуктів в еритроцитах та основ Шиффа у плазмі крові поросяті після технологічного стресу тільки посилюються, зокрема, до дії стресового чинника коефіцієнт кореляціі загальної очінки сили, врівноваженості і рухливості коркових прочесів із вмістом ТБК-активних продуктів становить - $r$ $=-0,57$ ( $p \leq 0,01)$, а після відлучення тварин до 5-ї доби зростає $-r=-0,83(p \leq 0,001)$. Функиіональні зв'язки основних властивостей коркових процесів зі вмістом основ Шиффа у плазмі крові поросят тільки через 5 діб після відлучення стають достовірними $(r=-0,54-0,65 ; p \leq 0,01-0,001)$.Вплив основних коркових процесів на вміст ТБК-активних продуктів до відлучення є досить істотний $\left(\eta^{2}{ }_{x}=0,41-0,76 ; p \leq 0,001\right)$, однак, після відлучення знижується. Лише рухливість коркових прочесів достовірно впливає на вміст основ Шифра у плазмі крові поросят $\eta 2 x=0,48(p \leq 0,001)$ i хоча після відлучення сила впливу дещо знижується, однак залишається достовірно - $\eta 2 x=0,20-0,23$ ( $p \leq 0,05-0,01)$.

Ключові слова: вища нервова діяльність, ТБК-активні продукти, основи Шиффа, поросята, відлучення, функиіональні зв'язки, сила впливу.

\section{Взаимосвязи интенсивности пероксидного окисления липидов с основными корковыми процессами у поросят при стрессе отьема}

\author{
А.В. Данчук, В.И. Карповский \\ olexdan@ukr.net
}

Национальный университет биоресурсов и природопользования Украины, ул. Героев Обороны, 15, г. Киев,

Технологический стресс (отъем) сопровождается ростом содержания ТБК-активных продуктов в эритроцитах и оснований Шиффа в плазме крови поросят (в 1,8-2,6 раза; $p \leq 0,001)$, что является общепризнанной биологической особенностью и не зависит от типологических особенностей высшей нервной деятельности. Установлены функциональные связи и влияние корковых процессов на содержание ТБК-активных продуктов в эритроцитах и оснований Шиффа в плазме крови поросят. Обратные функииональные связи основных свойств корковых процессов с содержанием ТБК-активных продуктов в эритрочитах и оснований Шиффа в плазме крови поросенку после технологического стресса только усиливаются, 6 частности, до действия стрессового фактора коэффициент корреляции общей оценки силь, уравновешенности и подвижности корковых прочессов с содержанием ТБК -активных продуктов составляет $-r=-0,57$ ( $p \leq 0,01)$, а после отъема животных до 5-го дня растет $-r=-0,83$ ( $p \leq 0,001)$. Функииональные связи основных свойств корковых проиессов с содержанием оснований Шиффа в плазме крови поросят только через 5 суток после отъема становятся достоверными $(r=$

Citation:

Danchuk, O.V., Karpovskiy, V.I. (2016). Intensity relationship with lipid peroxidation basic cortical processes in pigs at weaning stress. Scientific Messenger LNUVMBT named after S.Z. Gzhytskyj, 18, 3(70), 78-82. 
-0,54-0,65; $\leq \leq 0,01-0,001)$. Влияние основных корковых прочессов на содержание ТБК-активных продуктов до отлучения достаточно существенное $\left(\eta^{2} x=0,41-0,76 ; p \leq 0,001\right)$, однако, после отлучения снижается. Только подвижность корковых процессов достоверно влияет на содержание основ Шиффа в плазме крови поросят $\eta^{2} x=0,48(p \leq 0,001)$ и хотя после отлучения сила воздействия несколько снижается, однако остается достоверной - $\eta^{2}{ }_{x}=0,20-0,23(p \leq 0,05-0,01)$.

Ключевые слова: высшая нервная деятельность, ТБК-активные продукты, основания Шиффа, поросята, отлучение, функциональные связи, сила воздействия.

\title{
Intensity relationship with lipid peroxidation basic cortical processes in pigs at weaning stress
}

\author{
O.V. Danchuk, V.I. Karpovskiy \\ olexdan@ukr.net
}

\begin{abstract}
National university of life and environmental sciences of Ukraine, Heroes of Defense Str., 15, Kyiv, 03041, Ukraine
\end{abstract}

\begin{abstract}
Technological Stress (weaning) is accompanied by the growth of the content of TBA-active products in erythrocytes and Schiff bases in the blood plasma of pigs (in $1.8-2.6$ times; $r \leq 0.001$ ), which is a recognized feature of biological and does not depend on the typological characteristics of higher nervous activity. Established functional relationships and the influence of cortical processes for the maintenance of TBA-active products in erythrocytes and Schiff bases in the blood plasma of pigs. Reverse functional connection fundamental properties of cortical processes the content of TBA-active products in erythrocytes and Schiff bases in the blood the pig plasma after the process of stress are amplified, in particular, to an action of a stress factor correlation coefficient of overall evaluation strength, balance and mobility cortical processes containing TBA - active products is $-r=-0.57(r \leq 0.01)$, and after weaning animals to 5-day growing $-r=-0.83(r \leq 0.001)$. Functional connection of the basic properties of cortical processes with Schiff bases in the blood plasma of pigs only 5 days after weaning are reliable $(r=-0.54-0,65 ; r \leq 0,01-0,001)$. Effect of basic cortical processes in the content of TBA-active products before weaning quite substantial $\left(\eta^{2}{ }^{2}=0.41-0.76 ; r \leq 0.001\right)$, but, after weaning reduced. Only mobility of cortical processes significantly affects the content of Schiff bases in the blood plasma of pigs $\eta^{2} x=$ $0.48(r \leq 0.001)$ and even after weaning force of impact is somewhat reduced, but still reliable $-\eta^{2}{ }^{2}=0.20-0.23(r \leq 0.05-0.01)$.

Key words: higher nervous activity, TBA-active products, Schiff base, piglets, weaning, functional relationships, the strength of
\end{abstract} the impact.

\section{Ветуп}

Вища нервова діяльність (ВНД) відіграє провідну роль у пристосування організму до мінливих умов оточуючого середовища (Pavlov, 1949; Karpovs'kyj et al. 2000). Нервова система забезпечує існування організму шляхом регуляції фізіологічних процесів, зокрема, інтенсивності пероксидного окиснення ліпідів та активності системи антиоксидантного захисту (Naumenko, 1968).

Активні форми Оксигену утворюються переважно в процесі клітинного дихання і забезпечують синтез біологічно активних речовин, фагоцитоз, детоксикацію, мітоз, апоптоз, ротацію ліпідних та білкових компонентів плазматичних мембран і т.д. Процеси вільнорадикального окиснення лежать в основі метаболізму всіх клітин організму і тому можуть служити одним із критеріїв оцінки розвитку технологічного стресу, зокрема стресу відлучення (Vladimirov and Archakov, 1972).

Вторинні продукти пероксидації (малоновий діальдегід, ді- та триєнові кон'юганти) є токсичними для організму, тому знешкоджуються шляхом взаємодії із аміногрупами різних органічних сполук (амінокислоти, прості і складні білки, нуклеотиди, гормони, вітаміни) із утворенням основ Шиффа (ОШ) (Vladimirov and Archakov, 1972).

Тому актуальним напрямком досліджень $є$ встановлення взаємозв' язків та взаємовпливів інтенсивності пероксидації ліпідів із основними показниками коркових процесів (силою, врівноваженістю процесів збудження та гальмування та рухливістю) за технологічного стресу у свиней.

Мета $і$ завдання дослідження - дослідити взаємозв'язки показників інтенсивності пероксидного окиснення ліпідів із основними корковими процесами у поросят за стресу відлучення.

\section{Матеріал і методи досліджень}

Дослідження проводилися на свинофермі ТОВ СП «Нібулон» філія «Мрія» с. Сокіл Кам'янець- Подільського району Хмельницької області.

Для проведення даного експерименту було підібрано 47 поросят великої білої породи. До двомісячного віку поросята утримувались під свиноматками у типових приміщеннях. У 60-денному віці проводили відлучення, вакцинацію проти бешихи та формували групи на дорощування. Тварини в сформованих групах утримувались на сухому концентратному типі годівлі, доступ до води - вільний. Годівля свиней проводилась вволю.

У всіх тварин визначали силу, врівноваженість $\mathrm{i}$ рухливість нервових процесів модифікованої методикою розробленою на кафедрі фізіології, патофізіології та імунології тварин НУБіП України (Karpovs'kyj et al. 2000). В iï основі лежить вивчення (в типових індивідуальних станках) рухової реакції тварини на місці підкріплення кормом, швидкості вироблення умовного рухово-харчового рефлексу, ступеня орієнтовної реакції і зовнішнього гальмування, утворення переробки умовних рухово-харчових рефлексів і реакції тварини на гальмівний подразник. На підставі аналізу 
отриманого матеріалу було сформовано 4 групи тварин, по 10 голів у кожній: I група - сильний врівноважений рухливий тип (CBP); II група - сильний врівноважений інертний тип (CBI); III група - сильний неврівноважений тип ВНД (CH); IV група - слабкий тип вищої нервової діяльності (C). У 60, 61, та 65добовому віці у всіх тварин брали кров шляхом пункції передньої порожнистої вени. У еритроцитах крові поросят визначали вміст ТБК-активних продуктів, у плазмі крові визначали вміст основ Шиффа спектрофотометричним методом.

\section{Результати та їх обговорення}

Основними властивостями нервових процесів $є$ їх сила, врівноваженість збудження і гальмування та рухливість(Karpovs'kyj et al., Danchuk et al., 2005). Як видно 3 таблиці 1, показники кіркових процесів у свиней різних типів вищої нервової діяльності вірогі- дно відрізняються. Загальній показник кіркових процесів у свиней $\mathrm{CBI}, \mathrm{CH}$ та С типів ВНД нижче на $19,6 \%(\mathrm{p} \leq 0,01), 30,4 \%$ та $68,4 \%(\mathrm{p} \leq 0,001)$ відповідно до показників тварин СВР типу ВНД.

Результати проведених досліджень показують, що в період відносного спокою відсутня достовірна різниця у вмісті ТБК-активних продуктів в еритроцитах свиней сильних типів ВНД.

Пристосування свиней до дії стресора (відлучення, переведення в літній табір зі значними коливаннями температури протягом доби і перегрупування) супроводжується напругою адаптаційних механізмів. В результаті переходу метаболізму на інший рівень, в клітинах зростає утворення активних форм Оксигену у дихальному ланцюзі мітохондрій, що призводить до інтенсифікації ПОЛ (Vladimirov and Archakov, 1972) i супроводжується накопиченням ТБК-активних продуктів.

Таблиця 1

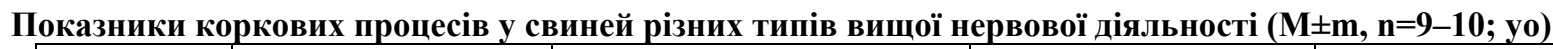

\begin{tabular}{|l|c|c|c|c|}
\hline \multicolumn{1}{|c|}{ Тип ВНД } & Сила & $\begin{array}{c}\text { Врівноваженість збудження } \\
\text { і гальмування }\end{array}$ & Рухливість & Середня оцінка \\
\hline СВР & $3,90 \pm 0,04$ & $3,80 \pm 0,15$ & $3,50 \pm 0,22$ & $3,73 \pm 0,06$ \\
\hline CВI & $3,50 \pm 0,22^{* *}$ & $3,70 \pm 0,19$ & $1,80 \pm 0,12^{* * *}$ & $3,00 \pm 0,35^{* *}$ \\
\hline CH & $3,1 \pm 0,08^{* * *}$ & $1,90 \pm 0,08^{* * *}$ & $2,80 \pm 0,15^{* * *}$ & $2,60 \pm 0,35^{* * *}$ \\
\hline C & $1,22 \pm 0,15^{* * *}$ & $1,22 \pm 0,15^{* * *}$ & $1,10 \pm 0,17^{* * *}$ & $1,18 \pm 0,04 * * *$ \\
\hline
\end{tabular}

Примітка. У цій і наступній таблиці вірогідні різниці із СВР типом ВНД: $\mathrm{P}<0,05$ - *; $\mathrm{P}<0,01$-**; $\mathrm{P}<0,001$ - ***.

Зростання вмісту ТБК-активних продуктів у еритроцитах свиней після відлучення (61 доба, в 1,8 2 рази; $\mathrm{p} \leq 0,001)$ є загально біологічною особливістю і не залежить від типу ВНД. Однак, у тварин сильних типів ВНД до 65-ї доби життя їх концентрація у еритроцитах знижується (на $15-39 \% ; \mathrm{p} \leq 0,01-0,001)$, а у тварин слабкого типу ВНД вірогідно не змінюється (табл. 2).

Таблиия 2

Вміст ТБК-активних продуктів в еритроцитах свиней та основ Шиффа у плазмі крові поросят $(\mathbf{M} \pm \mathbf{m}, \mathbf{n}=\mathbf{5})$

\begin{tabular}{|c|c|c|c|c|}
\hline \multirow{2}{*}{ Вік, діб } & \multicolumn{4}{|c|}{ Типи ВНД } \\
\hline & CBP & CBI & $\mathrm{CH}$ & $\mathrm{C}$ \\
\hline \multicolumn{5}{|c|}{ ТБК-активні продукти, нмоль/мл } \\
\hline До відлучення & $2,35 \pm 0,18$ & $2,37 \pm 0,14$ & $2,37 \pm 0,12$ & $2,84 \pm 0,03^{*}$ \\
\hline 1 доба & $4,58 \pm 0,09$ & $4,29 \pm 0,18$ & $5,01 \pm 0,20$ & $5,66 \pm 0,25 * *$ \\
\hline 5 доба & $2,78 \pm 0,21$ & $3,61 \pm 0,05 * *$ & $3,31 \pm 0,15^{*}$ & $5,49 \pm 0,40 * * *$ \\
\hline \multicolumn{5}{|c|}{ Основи Шиффа, во/мл плазми } \\
\hline До відлучення & $0,156 \pm 0,035$ & $0,164 \pm 0,024$ & $0,150 \pm 0,029$ & $0,212 \pm 0,034$ \\
\hline 1 доба & $0,353 \pm 0,031$ & $0,370 \pm 0,033$ & $0,384 \pm 0,037$ & $0,414 \pm 0,030$ \\
\hline 5 доба & $0,269 \pm 0,020$ & $0,325 \pm 0,037$ & $0,307 \pm 0,016$ & $0,418 \pm 0,027 * * *$ \\
\hline
\end{tabular}

Вміст основ Шиффа в плазмі крові поросят до відлучення достовірно не різнився, однак, прослідковується тенденція щодо вищого вмісту у тварин слабкого типу ВНД у порівнянні із показниками тварин сильних типів. Після відлучення проходить зростання вмісту ШО в плазмі крові тварин у 2 - 2,6 рази не залежно від типологічних особливостей нервової системи. До 5 доби після відлучення у плазмі крові тварин сильних типів ВНД вміст ОШ достовірно знижується (у 1,1 - 1,3 рази; $\mathrm{p} \leq 0,05-0,001)$, тоді, як у тварин слабкого типу ВНД дещо зростає, в наслідок чого стає достовірно вище $1,3-1,6$ рази $(\mathrm{p} \leq 0,001)$ від показника тварин сильних типів ВНД.
Проведені дослідження вказують обернені функціональні зв'язки основних властивостей коркових процесів із вмістом ТБК-активних продуктів в еритроцитах та основ Шиффа у плазмі крові поросят, які після технологічного стресу тільки посилюються (рис. 1). Так, до дії стресового чинника коефіцієнт кореляції загальної оцінки сили, врівноваженості і рухливості коркових процесів із вмістом ТБКактивних продуктів становив $-\mathrm{r}=-0,57$ ( $\mathrm{p} \leq 0,01)$, а після відлучення тварин до 5-ї доби зростає до показника $-\mathrm{r}=-0,83(\mathrm{p} \leq 0,001)$. 


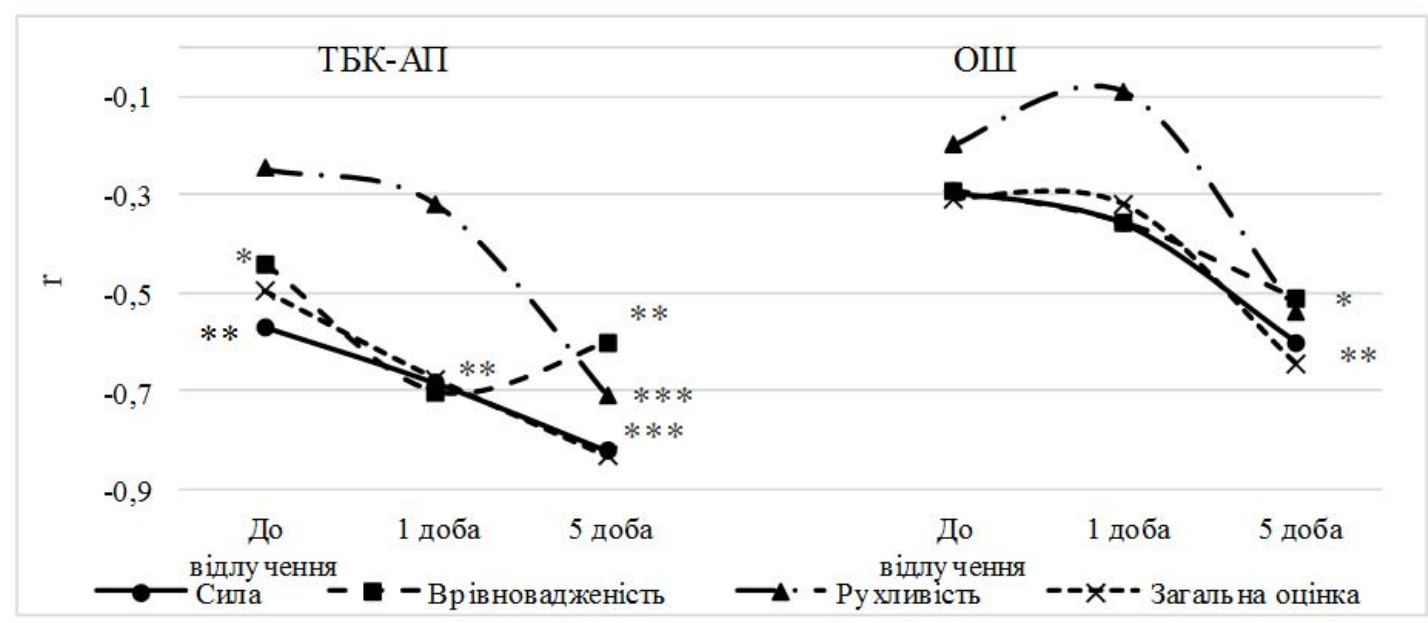

Рис. 1. Функціональний зв'язок (r) основних властивостей коркових процесів зі вмістом ТБКактивних продуктів в еритроцитах та основ Шиффа у плазмі крові поросят, $\mathbf{n = 2 0}$

Функціональні зв'язки основних властивостей коркових процесів зі вмістом основ Шиффа у плазмі крові поросят, як до відлучення, так і через добу після ного є недостовірними, однак, через 5 діб після відлучення вони суттєво посилюються і зростають до показників $-\mathrm{r}=-0,54-0,65$ ( $\mathrm{p} \leq 0,01-0,001)$. Отже, стано- влення функціональних зв'язків основних властивостей коркових процесів під час адаптації тварин із вмістом ОШ можна розглядати як вплив коркових процесів на знешкодження вторинних продуктів пероксидації ліпідів.

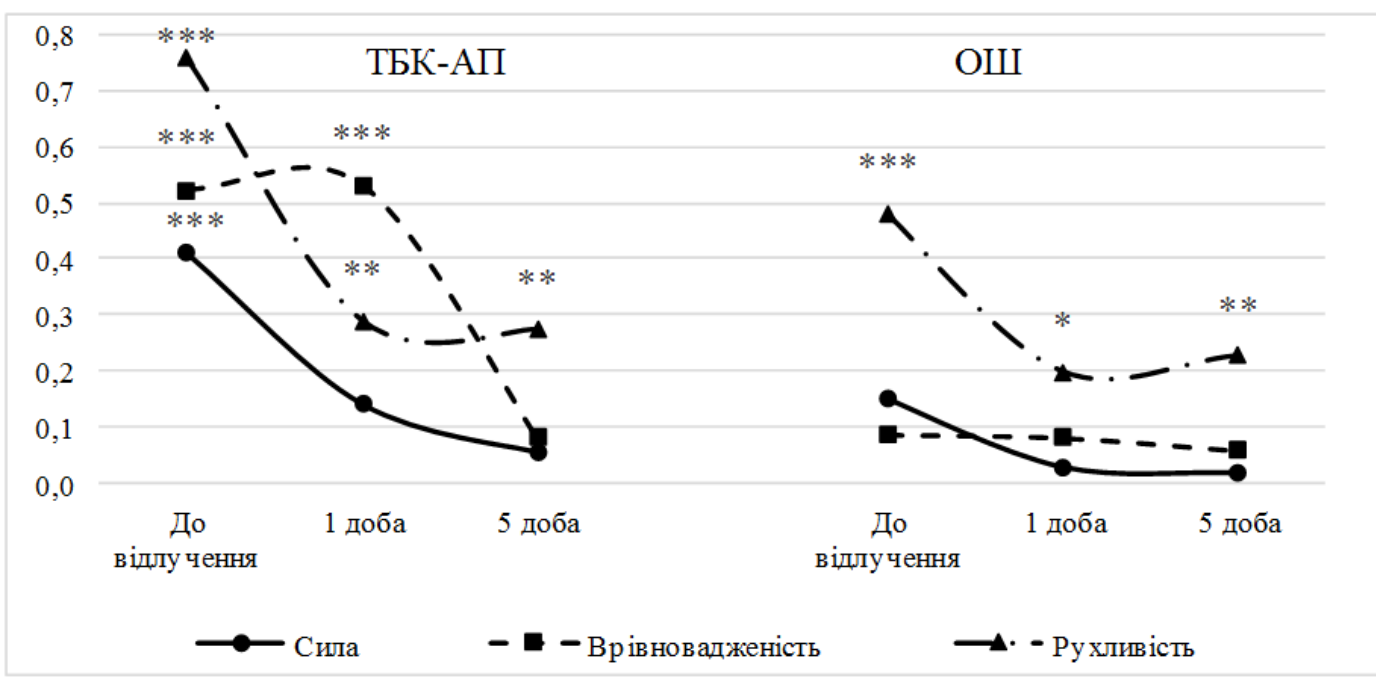

Рис. 2. Сила впливу основних властивостей коркових процесів на вміст ТБК-активних продуктів в еритроцитах та основ Шиффа у плазмі крові поросят, $\eta^{2} x, n=20$

Встановлено достовірну силу впливу основних коркових процесів на вміст ТБК-активних продуктів до відлучення $\left(\eta^{2}=0,41-0,76 ; p \leq 0,001\right)$. Після відлучення протягом 5 діб проходить істотне зниження впливу основних характеристик коркових процесів в наслідок чого вплив сили та врівноваженості стає недостовірним (рис. 2).

Встановлено відсутність достовірної сили впливу сили та врівноваженості коркових процесів на вміст ОШ в сироватці крові поросят протягом дослідного періоду $\left(\eta^{2} x=0,02-0,15\right)$. Однак, рухливість коркових процесів достовірно впливала на вміст ОШ в сироватці крові поросят до дії технологічного подразника $\eta^{2}$ х $=0,48(\mathrm{p} \leq 0,001)$ і хоча після відлучення сила впливу дещо знижується, однак залишається достовірно $\eta^{2}=0,20-0,23(\mathrm{p} \leq 0,05-0,01)$.

\section{Висновки}

Незалежно від типу ВНД дія стресового фактору супроводжується підвищенням вмісту ТБК-активних продуктів в еритроцитах та основ Шиффа у плазмі крові поросят. Встановлено достовірні обернені функціональні зв'язки основних властивостей коркових процесів із вмістом ТБК-активних продуктів в еритроцитах та основ Шиффа у плазмі крові поросят, які після технологічного стресу тільки посилюються. Вплив основних коркових процесів на вміст ТБКактивних продуктів до відлучення є досить істотний 
$(\eta 2 \mathrm{x}=0,41-0,76 ; \mathrm{p} \leq 0,001)$, однак, після відлучення знижується. Лише рухливість коркових процесів достовірно впливає на вміст основ Шиффа у плазмі крові поросят.

Перспективи подальших досліджень полягають у розробці нових методів профілактики та корекції стресових станів сільськогосподарських тварин із урахуванням типологічних особливостей вищої нервової діяльності.

\section{Бібліографічні посилання}

Pavlov, I.P. (1949). Fiziologicheskoe uchenie o tipah nervnoj sistemy, temperamentov. Poln. sobr. trud. 3, 369-377 (in Ukrainian).

Naumenko, V.V. (1968). Nekotorye osobennosti vysshej nervnoj dejatel'nosti i tipy nervnoj sistemy u svinej: avtoref. dis. na soiskanie uchenoj stepeni dokt. biol. nauk: spec. 802 «Veterinarnaja fiziologija». L'vov (in Ukrainian).
Danchuk, V.V. (2006). Peroksydne okysnennja u sil's'kogospodars'kyh tvaryn i ptyci, Kam'janec'Podil's'kyj: Abetka (in Ukrainian).

Danchuk, O.V., Tyhonov, M.M., Danchuk, V.V., Cepko, N.L., Danchuk, O.V., Dobrovol's'kyj V.A. (2005). Pokaznyky krovi porosjat-sysuniv za umov intensyfikacii' vil'noradykal'nogo okysnennja, Visnyk Dnipropetrovs'kogo derzhavnogo agrarnogo universytetu. 2, 86-89 (in Ukrainian).

Karpovs'kyj, V.I., Trokoz, V.O., Kryvoruchko, D.I., Trokoz, A.V., Shesteryns'ka V.V., Vasyliv, A.P. (2000). Metodyka vyznachennja typiv vyshhoi' nervovoi' dijal'nosti svynej u vyrobnychyh umovah, http://www.inenbiol.com/ntb/ntb7/20.pdf. (in Ukrainian).

Danchuk,V.V., Danchuk, O.V., Cepko, N.L. (2004). Oksydacijnyj stres-patologija chy adaptacija? Zhurnal Tvarynnyctvo Ukrai'ny. 4, 21-23 (in Ukrainian).

Vladimirov, Ju.A., Archakov, A.I. (1972). Perekisnoe okislenie lipidov $\mathrm{v}$ biologicheskih membranah. M.: Nauka (in Russian).

Стаття надійшла до редакиії 30.09.2016 